\title{
Rusland går til valg
}

\section{Lars P. Poulsen-Hansen}

\section{Valgkampen forud for Dumavalget er begyndt.}

Omkring ti partier forventes at stille op, men ifølge det oppositionelle politiske ugeblad Novoje Vremja er den russiske befolkning overbevist om, at hverken valgkampen eller valget vil få indflydelse på deres hverdag

Den 2. september 2007 undertegnede den russiske præsident Vladimir Putin et dekret, der bekendtgjorde, at valget til det russiske parlaments underhus, Statsdumaen, skal finde sted den 2. december 2007. Det var det officielle startskud til valgkampen, men Rusland havde længe før udskrivningen af valget været præget af det forestående Dumavalg og det efterfølgende præsidentvalg $\mathrm{i}$ marts 2008.

Hvor politisk stabilt Rusland end forekom at være, og hvor selvsikker præsident Putin end virkede udadtil, kunne man spore en vis nervøsitet i den russiske ledelse op til den samlede valgkamp, som ville komme til at vare et halvt år. Det var, som om man ikke var helt tryg ved udfaldet; det orange spøgelse fra Ukraine lurede i horisonten mod vest, og duften af rosenrevolutionen i Georgien i 2003 kunne Kaukasus' tinder ikke holde tilbage, og i foråret 2007 slog de russiske myndigheder hårdt ned på den udenomsparlamentariske opposition, hvilket blev betegnet som et udtryk for svaghed af en af de unge oppositionspolitikere, Marija Gajdar, der er datter af Jegor Gajdar, daværende præsident Boris Jeltsins førende økonomiske reformpolitiker 1991-1993.

Meget stod på spil for magthaverne og de politiske aktører, der kæmpede for magt og politisk indflydelse, selvom der næppe ville blive rokket ved de store linjer i den indenrigs- og udenrigspolitik, Putin havde udformet under sine knap otte år i Kreml.

Det oppositionelle politiske ugeblad Novoje Vremja/The New Times 
kommenterede udskrivningen af valget på følgende måde:

"I Rusland er parlamentsvalgkampen officielt startet, og den skal slutte den 2. december: Den vil kun tilnærmelsesvis få noget med et reelt valg at gøre. Ikke desto mindre vil alt liv i landet fra nu af uundgåeligt blive underordnet valget. Alle politikernes initiativer, alle betydningsfulde tv-programmer, al optræden i æteren og på avisernes sider af reelle og falske efterfølgere (til Putin lph) og deres satellitter vil blive underordnet systemet 'Gas-vyborys' interesser (det automatiske stemmeoptællingssystem - lph).

Vi står foran et ærgerrighedens og dumhedens marked. Vi står foran eventyragtige pr-initiativer i lighed med erobringen af Arktis' bund (anbringelsen af det russiske flag på den undersøiske Nordpol i sommeren 2007 - lph). Rundhåndede løfter fra politikerne til de arbejdende og ikke så meget arbejdende. Løfter, der tælles i milliarder af rubler.

Det russiske folk vil stå disse vilde udskejelser igennem, for det er overbevist om, at valgkampen og dens resultater ikke vil få indflydelse på dets daglige liv. Det bliver sværere for de embedsmænd, der har ansvaret for statens budget, og for dem, der vogter over Stabiliseringsfonden: de vil blive udsat for et uhørt pres. Den eneste egentlig politiske intrige ved valgkampen består i, hvor bred 'Forenet Ruslands' offensiv vil blive, og hvorvidt magtha- vernes andet ben, 'Retfærdigt Rusland', kan blive en reel konkurrent til de 'forenede russere'."

\section{Den nye Duma}

Det forestående Dumavalg er det femte i det postsovjetiske Rusland. Den første postsovjetiske Duma blev valgt i december 1993, samtidig med at der afholdtes folkeafstemning om den forfatning, som indeholdt bestemmelserne om det nye parlament - en dristig fremgangsmåde. Dumaen, der fik 450 medlemmer, 225 valgt på partilister og 225 valgt i enkeltmandskredse, tog sit navn fra den repræsentative forsamling, tsar Nikolaj II følte sig nødsaget til at give sit land ved Oktobermanifestet 1905 efter urolighederne samme år. Indtil Februarrevolutionen i 1917 mødtes fire dumaer, de første to kun få måneder hver i hhv. $1906 \mathrm{og}$ 1907, den tredje fra 1907 til 1912 og den fjerde fra 1912 til 1917.

Den første postsovjetiske Duma, der ifølge den nye forfatning kun skulle sidde to år, kaldtes som udtryk for den historiske kontinuitet således også den femte Duma.

Dumavalget i december 2007 finder ligesom Dumavalgene i 1995, 1999 og 2003 sted til den i forfatningen fastsatte tid, dvs. ved udløbet af sin fireårige valgperiode. Der har i det postsovjetiske Rusland ikke været udskrevet parlamentsvalg i utide. Den kommende Duma vil blive valgt på en anden måde end de foregående. 
Alle 450 medlemmer skal vælges på partilister ved forholdstalsvalg. Valg i enkeltmandskredse, der sikrede hver nok så lille selvstændige region i Rusland repræsentation i Dumaen, er afskaffet og erstattet med et indviklet system af regionale valggrupper (se nedenfor), der vil medføre, at befolkningsrige regioner løber med mandaterne, og tyndtbefolkede regioner ikke bliver repræsenterede.

Det er forbudt at danne valgblokke mellem flere partier, spærregrænsen er hævet fra 5 til 7 procent, den minimale valgdeltagelse på 20 procent for at gøre valget gyldigt er ophævet, og det vil ikke være muligt at afgive sin stemme ' $m o d$ alle kandidater', som 4,7 procent af vælgerne gjorde i 2003 .

Hertil kommer, at partier, der ikke er repræsenteret i Dumaen, skal stille med et 'valgdepositum' på 60 mio. rubler (12.654.000 kr.) eller præsentere 200.000 gyldige underskrifter til støtte for deres kandidatliste. Hvis de nye partier får 4 procent af stemmerne, får de dog deres penge tilbage.

Der er uenighed blandt de russiske politiske kommentatorer om, hvad ændringerne vil komme til at betyde for sammensætningen af Dumaen, men ét er sikkert: det bliver svært for partier uden for Dumaen at komme ind. Og det bliver svært for nye partier at stille op.

Da Dumaen mødtes efter sommerferien i begyndelsen af septem- ber, var den sammensat således: Forenet Rusland 303 medlemmer Den Russiske Føderations Kommunistiske Parti 47 medlemmer Retfærdigt Rusland 33 medlemmer Ruslands Liberal-Demokratiske Parti 31 medlemmer

Den Folkeligt-Patriotiske Union Fædrelandet 8 medlemmer Løsgængere 23 medlemmer

Af partiernes Dumagrupper menes de første tre at være sikre på at blive repræsenteret i den ny Duma, men inden for grupperne forventes der store udskiftninger. Således bliver formentlig kun 200 af Forenet Ruslands Dumamedlemmer genopstillet, og kun 10 af Retfærdigt Ruslands gruppe vil undgå partiformandens 'udrensninger' i gruppen.

I ugeavisen Moskovskije novosti har Igor Dmitrijev påpeget, at der i hver Dumagruppe findes fire slags medlemmer: fremtrædende partiledere af føderalt og regionalt format; arbejdsduelige og uanselige apparattikker, vælgermagneter fra kulturens og sportens verden samt 'pengesækkene'. I Forenet Ruslands gruppe sidder således 23 af de 28 rubelmilliardærer, der er medlemmer af Dumaen.

\section{Partidannelsen}

I Rusland, der som en ung stat er kendetegnet ved at have eller ønske sig faste regler om alting, har man en lov fra 2001 om politiske partier, disses dannelse og virke. Her står 
der, at et politisk partis hovedformål er følgende: at danne den offentlige opinion; at uddanne og opdrage borgerne politisk; at udtrykke borgernes meninger om hvilke som helst spørgsmål i samfundslivet og viderebringe disse meninger til den brede offentlighed og statsmagtens organer; at opstille kandidater til valg af præsident, valg af Dumamedlemmer osv. nedefter.

Af disse formål lyder det andet pudsigt nok som et levn fra gamle dage. Og Jeltsins ministerpræsident i årene 1992-98, Viktor Tjernomyrdin, har da også karakteriseret de postsovjetiske partidannelser, som han selv har deltaget $i$, med ordene: "Hvilket parti vi end danner i Rusland, kommer der et SUKP (Sovjetunionens Kommunistiske Parti) ud af det." En bemærkning, der med rette er blevet et bevinget ord i russisk politik.

Partiloven foreskriver, at et politisk parti for at blive registreret som sådant skal have mindst 50.000 medlemmer. Det skal dertil have afdelinger med mindst 500 medlemmer i over halvdelen af Ruslands 84 regioner, og i hver af de øvrige regionale afdelinger skal der være mindst 250 medlemmer.

Hvis partiet ikke er repræsenteret i Dumaen og vil opstille til valget skal det som nævnt enten betale et depositum eller aflevere 200.000 underskrifter og vel at mærke: ikke flere end 10.000 pr. region. De kan altså ikke lige indsamles i Moskva eller Skt. Petersborg.
Ved valgkampens start havde Den Centrale Valgkommission registreret 15 partier, der opfyldte kravene til partidannelse. Af disse mentes kun højst 10 at kunne/ville stille op til valget.

Jo, der er i og for sig mange partier, skrev Den Uafhengige Avis i en kritisk kommentar til det politiske liv uden for hovedstæderne, men det er helt umuligt at finde ud af, hvad der adskiller dem. I reglen 'syder partilivet' inden for Haveringgaden i Moskva, men i regionerne finder man kun tegn på liv hos de partier, der har en 'stabil finansiering' fra landets politiske center.

Avisens korrespondenter måtte ude i landet nærmest lede med lup efter 'celler' af enkelte 'højtlarmende' (at dømme efter deres selv-pr i Moskva) partier.

Nogle af dem er usynlige, andre er gået dybt under jorden og giver ingen tegn på liv fra sig, og endnu andre blæser sig op ved hjælp af babusjka-pensionister, der stadig ser ud til at tro på gyldigheden af den sovjetiske forfatnings artikel 6 (om kommunistpartiets ledende rolle i samfundet): "Der er ikke tale om kamp på ideer og partiprogrammer og andet, som skulle adskille det ene parti fra det andet."

Det generelle problem i russisk politik er ifølge ugeavisen Moskovskije novostis politiske kommentator, Aleksej Zudin, at partier og valg ikke er institutionelt rodfæstede som sådanne. 


\section{Hvad byder partierne på?}

\section{Forenet Rusland:}

Det nuværende 'magtens parti' blev dannet i 2001 ved en sammenlægning af partierne Enhed og Fædrelandet. Dets symbol er en bjørn indtegnet i det russiske flag, og medlemmerne kaldes derfor 'bjørnene'. Det har afdelinger i alle regioner og tæller ifølge sin hjemmeside

\subsubsection{0 medlemmer.}

Dumagruppen var i begyndelsen af september på 303 medlemmer og udgør således den kvalificerede majoritet, der skal til for i givet fald at ændre forfatningen, der står uændret siden 1993.

Partiets formand er fra 2004 Boris Gryzlov (f. 1950), der i 2003 var blevet formand for Dumaen. Han er uddannet som radioingeniør og gjorde som sådan karriere på en fabrik for elektroniske instrumenter i Skt. Petersborg. I 1999 blev han valgt ind i Dumaen for partiet Enhed og blev formand for dets Dumagruppe; i marts 2001 blev han udnævnt til indenrigsminister, hvilket han var, indtil han blev formand for Dumaen. I 2005 ydede han i lighed med Tjernomyrdin sit flotte bidrag til den postsovjetiske russiske politiks skatkammer af bevingede ord med bemærkningen: "Dumaen er ikke sted, hvor der skal diskuteres."

Partiet står last og brast med præsident Putin, der åbenlyst støtter Forenet Rusland, selvom han som præsident forventes at stå uden for partierne. Putin figurerer på partiets hjemmeside, og dets program er identisk med den plan for landets udvikling i de kommende år, han fremlagde i sit årlige budskab til parlamentets to kamre den 26. april 2007.

Putin holdt en mindre peptalk på et møde for partiets Dumamedlemmer i juni 2007, og han forventedes at komme til partiets kongres 1.-2. oktober.

Ifølge Gryzlovs kollega, formanden for parlamentets overhus, Føderationsrådet, Sergej Mironov, gør præsidentens administration alt arbejdet for Forenet Rusland. Det lægger ingen skjul på, siger han: "Det er et parti af embedsmænd, der forsvarer bureaukratiets interesser ... og de har ingen andre muligheder for at sejre end at bruge den 'administrative resurse'. De kan ikke levere ideer med indhold; de overtager kun alt det, som Vladimir Putin har gjort og opnået. De har endog kaldt deres program 'Putins plan'. Heri ses også partiets ideologiske armod."

Putinplanen omfatter tre hovedopgaver: 1) Initiativer til at vende den negative befolkningstilvækst; 2) En fornyet indsats mod korruptionen; 3) Skabelse af en innovativ $\varnothing$ konomi. Mere specifikt vil partiet skabe bedre forhold for pensionisterne, forbedre sundhedsvæsenet og uddannelsessystemet, støtte udviklingen af industri og landbrug, udligne forskellene mellem regio- 
nerne, bekæmpe bureaukratiet og styrke partisystemet ved at danne 'partiregeringer' i regionerne (altså regionsledelser, der fremgår af et politisk flertal i den regionale lovgivende forsamling). Endelig vil partiet støtte ngo'ernes udfoldelsesmuligheder.

På det udenrigspolitiske område nøjes planen med at konstatere, at Rusland har styrket sin internationale position og ønsker at fremstå som et af verdens ledende lande. Man går ind for en demokratisering af de internationale relationer og vender sig mod dobbeltstandarder. Samtidig med at der tales om Ruslands historiske mission, der består i 'at forene verdenscivilisationens forskellige poler og blive et førende intellektuelt center i den moderne verden', nævnes det, at man i Rusland udrydder alle forekomster af xenofobi og nationalisme.

I sin peptalk fremhævede Putin det som et plus ved partiet, at det afstår fra populisme og tomme løfter. Men tilbage står spørgsmålet, hvad der bliver af partiets program, når Putin ikke længere er præsident.

\section{Retferdigt Rusland:}

Partiet er dannet så sent som i oktober 2006 på grundlag af partierne Fædrelandet, Pensionisterne og Livet som en slags officiel venstrecentristisk modpol til det højrecentristiske Forenet Rusland - måske med det formål at stække kommunistpartiets indflydelse. Dets symbol er det russiske flag med partiets navn indskrevet og de tre oprindelige partiers navne nedenunder. Partiet har afdelinger i næsten alle regioner, men angiver ikke medlemstallet på sin hjemmeside. Dumagruppen havde ved udskrivelsen af valget 33 medlemmer.

Ved dannelsen af partiet blev formanden for parlamentets overhus, Føderationsrådet, Sergej Mironov (f. 1953), valgt til formand. Han har aftjent sin værnepligt i de sovjetiske luftbårne styrker(!), er uddannet som geofysiker og gjorde karriere som sådan indtil 1991. Siden har han taget bl.a. en juridisk grad med udmærkelse. Sin politiske karriere begyndte han i 1994 i Skt. Petersborgs lovgivende forsamling, dengang en endnu ukendt Vladimir $\mathrm{Pu}$ tin arbejdede $i$ byens administration. I juni 2001 blev han valgt som Skt. Petersborgs repræsentant i Føderationsrådet, hvis formand han blev i december samme år. I 2003 blev han genvalgt til begge poster. Mironov er en svoren tilhænger af Putin, hvis kontrafej dog ikke figurerer på partiets hjemmeside.

Partiets formål er at skabe en stærk, socialt orienteret og retfærdig stat og et samfund, hvor man holder traditionerne i hævd, er stolt af sin historie, respekterer den ældre generation og skuer trygt ud i fremtiden. Med henblik herpå vil partiet bidrage til at udvikle et demokratisk samfund, bekæmpe korruptionen og embedsmandsvældet, bevare lan- 
dets kultur og skabe lige forhold for alle borgere, uafhængigt af deres sociale status. Partiets slogan er 'Vi er det arbejdende menneskes parti'. Partiet vil følgelig beskytte de arbejdende, sikre borgerne en værdig levestandard og udrydde social uretfærdighed.

På sin politiske platform af 26 . februar 2007 erklærer partiet, at det vil udrydde fattigdommen, hæve pensionerne, skabe civiliserede boligforhold, sætte ind på at øge befolkningstallet, få sundhedsvæsenet op på europæisk niveau, gøre noget for landets 13 mio. invalider, bekæmpe alkoholisme og narkomani, udvikle små og mellemstore virksomheder, effektivisere landbruget, hæve uddannelsen til europæisk niveau, sikre Ruslands intellektuelle lederskab i verden, lette de unges forhold, forbedre miljøet, bringe den illegale indvandring under kontrol, bekæmpe korruptionen, der skal sidestilles med landsforræderi (det samlede bestikkelsesbeløb er på størrelse med statens budget), øge tilliden til retsvæsenet samt øge statsstøtten til det militær-industrielle kompleks og give det militære personel 'en værdig status'.

Platformen indeholder ikke nogen egentlig industripolitik, og i et interview i dagbladet Izvestija i september talte Mironov kun om at bruge nogle af pengene i Stabiliseringsfonden til at bygge nye metrostationer i landets millionbyer og om at modernisere flyindustrien. $\mathrm{Og}$ med hensyn til forholdet til omverdenen står der kun, at den omstændighed, at Rusland som en multinational og polykonfessionel stat rummer en mangfoldighed af kulturer, er 'vores konkurrencefordel'.

Meget i partiets platform minder vælgerne om gamle dage, men partiets koncept kaldte formanden i et interview i Den Uafhengige Avis i juni 2007 for 'ny socialisme', der skal forstås som 'statens retfærdige forhold til sine borgere' eller en realisering af forfatningens artikel 7 om Rusland som en socialstat, der ifølge Mironov foreløbig kun er en hensigtserklæring.

Partiet går da også ind for den private ejendomsret og vil ikke revidere privatiseringen, men ser samtidig gerne staten som en aktiv medspiller i de strategiske industribrancher. Mironov overlader det generøst til kommunistpartiets formand, Gennadij Zjuganov, at vende sig til fortiden, til mangelsocialismen og statens totale kontrol over alt og alle.

\section{Den Russiske Føderations Kommunisti- ske Parti (KPRF):}

Det nuværende kommunistparti er arvtager til Sovjetunionens Kommunistiske Parti (SUKP). Det blev gendannet i 1993 efter at have været forbudt af Boris Jeltsin siden efteråret 1991. Partiets symbol er en rød fane med bogstaverne KPRF forneden og ovenover en hammer, en segl og en bog som symbol på unionen af arbejdere i byen, på landet 
og inden for kultur og videnskab, omgivet af partiets slogan 'Rusland, arbejde, folkestyre, socialisme'. Dets hymne er stadig 'Internationale'. Partiet har afdelinger i alle landets regioner og 547.000 medlemmer. Dumagruppen var ved udskrivningen af valget med sine 47 medlemmer den næststørste.

Partiets formand har siden 1993 været Gennadij Zjuganov (f. 1944), der er uddannet som fysik- og matematiklærer og dels virkede som sådan, dels gjorde tjeneste i en ABCsporingsenhed i Sovjethæren, før han i 1966 trådte ind i SUKP og året efter startede sin partikarriere inden for Komsomol, idet han fortsatte lærergerningen til 1970. 1989-90 endte han karrieren på posten som souschef i SUKP's Centralkomités ideologiske afdeling.

Han har været medlem af Dumaen siden 1993, og op til præsidentvalget i 1996 var han en alvorlig konkurrent til den siddende præsident Jeltsin, som han tabte til med 31,96 procent af stemmerne i første omgang og 40,41 procent $i$ anden omgang. Han tabte stort til Putin ved præsidentvalget i 2000, stillede ikke op i 2004, men ventes at stille op til valget i marts 2008.

Den korte version af partiprogrammet på partiets hjemmeside lyder på, at partiet fortsætter SUKP's arbejde, idet det bygger på en kreativ udvikling af marxismen-leninismen og har som mål at opbygge socialismen - et samfund med social retfærdighed på kollektivismens, frihedens og lighedens principper og går ind for ægte folkestyre i form af sovjetter og for en styrkelse af den føderative multinationale stat.

Det er et parti af patrioter og internationalister, hedder det bredtfavnende, og et parti for mellemfolkeligt venskab. Partiet forsvarer de kommunistiske idealer og arbejderklassens, bondestandens, intelligentsiaens og alle arbejdende menneskers interesser.

Alt dette er mere udførligt beskrevet i partiprogrammet, der indledningsvis konstaterer, at Rusland befinder sig på en tragisk korsvej, og at det nuværende regime med bedrag og vold prøver at føre folkeslagene i fædrelandet til en barbarisk, primitiv kapitalisme.

Det er den politiske reaktions og det sociale tilbageskridts vej, den nationale katastrofes vej, der fører til den russiske civilisations undergang, står der. Kort sagt: Rusland risikerer at få samme skæbne som Sovjetunionen. Og det er netop partiets mål at genskabe Sovjetunionen. Men det fremgår ikke af programmet, hvad den skal i den store verden, der stadig er karakteriseret ved en kamp mellem kapitalisme og socialisme.

Alt dette lyder i en udenforståendes ører meget konservativt og reaktionært, som et opråb fra højrefløjen, men i Rusland kaldes kommunistpartiet traditionelt stadig et venstrefløjsparti. Zjuganov mener tilmed, at det er det eneste ægte og 
ærlige parti; alle de andre er attrapper.

\section{Det Liberal-Demokratiske Parti (LDPR):}

Som Sovjetunionens Liberalt-Demokratiske Parti blev dette parti det første, der dannedes efter ophævelsen af SUKP's magtmonopol i marts 1990, og dets formand har siden da været Vladimir Volfovitj Zjirinovskij (f. 1946), der i de første mange år af sit politiske virke søgte at skjule sin jødiske herkomst med bemærkningen: "Min mor er russer, og min far (med fornavnet Volf - lph) jurist."

Han er ubetinget den mest farverige russiske politiker, Dumaens enfant terrible, der aldrig er mundlam og godt kan gribe til korporligheder over for sine modstandere. Zjirinovskij har en universitetsgrad i faget 'Tyrkiet og tyrkisk sprog', suppleret med en juridisk eksamen, og han har gjort tjeneste i Sovjethæren i Det Transkaukasiske Militærdistrikt. 1977-83 var han ansat i det sovjetiske justitsministerium, og 1983-90 var han leder af den juridiske afdeling på forlaget Mir. Han har deltaget i præsidentvalgene i 1991, 1996 og 2000, men lod sig i 2004 repræsentere af sin bodyguard. Han ventes at stille op i 2008.

Partiets mærke er forkortelsen af navnet i gult på blå baggrund. Det har afdelinger $i$ alle landets regioner og over 500.000 medlemmer. Partiet og Zjirinovskij har været præsenteret i Dumaen siden 1993, senest med 31 medlemmer.
I partiets program af 2007 står der om præsidentmagten: "Den russiske stats leder skal være som Ivan den Grusomme, som Peter den Store, ja som Stalin, men ikke som Brezjnev, Gorbatjov eller Jeltsin.” Der skal være en stærk præsident og et demokratisk valgt parlament, og præsidenten skal danne regeringen på grundlag af det parlamentariske flertal.

Mens tesen om præsidenten lyder meget reaktionær, er forslaget om regeringsdannelsen meget progressivt, for så langt er man endnu ikke nået i Rusland, hvor præsident $\mathrm{Pu}$ tin tre måneder før valget udnævnte en ny ministerpræsident, der måtte forventes at fortsætte $\mathrm{i}$ embedet $\mathrm{i}$ hvert fald til præsidentvalget i marts 2008.

I et partimanifest hedder det indledningsvis: "Rusland opgiver det ene holdepunkt efter det andet. Hæren er solgt og udplyndret. Kulturen er uanstændig og perverteret, produktionen er brudt sammen, regeringen lider af defekter, myndigheder og lovgivere er korrupte, landbruget er ved at dø, maskinbygningen er ynkelig. Der er ikke den branche, de fede businesskøtere ikke har gravet i."

Som det russiske populistiske protestparti par excellence vil LDPR rette op på alle disse forhold og flere til. Som talsmand for de undertrykte og forurettede står LDPR i opposition til alle embedsmænd og guvernører, til regeringen og præsi- 
denten, og partiet vil gøre noget for vælgerne på bl.a. følgende områder: boligforhold, sundhedsvæsen, arbejdsløshed, pensioner, uddannelse, energiforsyning, retsvæsen, landbrug, bekæmpelse af korruption.

I partiets program er to sider viet udenrigspolitikken. Her hedder det, at Rusland skal genforenes med Hviderusland, Ukraine, Kazakhstan og de russiske regioner i Baltikum og have adgang til Det Indiske Ocean og Mellemøsten. Tyskland anføres som Ruslands hovedpartner i Europa, hvor man skal revidere forholdet til OSCE, NATO, Europa-Parlamentet og Europarådet, der kan blande sig i Ruslands interne anliggender og handle imod dets nationale interesser.

USA betegnes som den største antirussiske kraft, der efter at have ødelagt Sovjetunionen nu er ude på at splitte Rusland op i en række stater, der er afhængige af Vesten. Japan skal ikke gøre sig håb om at få de sydlige Kuriler tilbage. Kina skal man handle med, men samtidig skal indvandringen af kinesere stoppes, så man ikke mister en betydelig del af Ruslands territorium. Forholdet til Indien er problemfrit.

Endelig skal Rusland med sin 20 mio. store muslimske befolkningsgruppe melde sig ind i Den Islamiske Samarbejdsorganisation og samarbejde med Iran og Irak, Syrien og SaudiArabien, Jordan og Afghanistan.

Partiets manifest slutter med ordene: "En stemme for LDPR er en stemme for fornuftens sejr over nattens, mørkets og voldens kræfter."

Unionen af Højrekrcefter (SPS):

Dette parti er dannet i 2001 på grundlag af en række mindre partier og politiske bevægelser, herunder Ruslands Demokratiske Valg, der blev oprettet i 1994 af Jeltsins tidligere premierminister Jegor Gajdar.

Det er ikke repræsenteret i den nuværende Duma, og det spås ikke store chancer for at komme ind. Det har 60.000 medlemmer, men er repræsenteret med over 1.000 lokalafdelinger i alle landets regioner. Desuden fremhæver det på sin hjemmeside, at det har 101 medlemmer i 43 af de 84 regionale parlamenter. Partiets symbol er dets navn på baggrund af det russiske flags farver, og dets hymne er Mikhail Glinkas 'Patriotisk sang' (uden ord - lph), som var Ruslands nationalmelodi 19912001. Partiets slogan er 'Frihed. Ejendomsret. Retssikkerhed'.

Formand er siden 2005 Nikita Belykh (f. 1975), der har en teknisk og økonomisk uddannelse og har været på studieophold i Oxford. Han har gjort karriere $\mathrm{i}$ finansverdenen $\mathrm{i}$ Permregionen, hvor han blev generaldirektør for en investeringsbank og viceguvernør for regionen.

Partiet præsenterer sig som en konsekvent forsvarer af liberale principper i politik og økonomi. Dets mål er at skabe et civilt samfund og en demokratisk retsstat i Rusland, at realisere forfatningens 
principper om føderalisme og lokalt selvstyre og at fremme demokratiets og liberalismens værdier. Partiets program hedder 'Horisont 20072017. Giv Rusland dets fremtid tilbage.' Rusland skal bevæge sig mod frihed, demokrati og markedsøkonomi, og det skal være lige så godt at leve i Rusland som i et hvilket som helst europæisk land.

Blandt partiets primære opgaver er at gøre økonomien mindre afhængig af eksporten af olie og gas, at fremme privat foretagsomhed, at beskytte miljøet, at skabe uafhængige massemedier og forbyde statslig censur, at vedtage en valglov, som gør det umuligt for magthaverne i forvejen at bestemme valgresultatet. På længere sigt vil partiet også afhjælpe de problemer, som de øvrige partier vil gøre noget ved.

På det udenrigspolitiske område tager partiet afstand fra 'den skæbnesvangre leflen for autoritære regimer' og går ind for relationer med verdens førende demokratiske lande. Og så rejser man spørgsmålet om russisk medlemskab af EU på længere sigt. Her og nu ønsker man visumfrihed for russiske borgere i EU.

Unionen af Højrekræfter ligner ligesom partiet Jabloko, som har endnu mindre chancer for at komme ind i Dumaen, på mange måder et europæisk parti, og i den offentlige opinion i Rusland ses de da også som provestligt orienterede oppositionspartier, hvilket ikke tæller til deres fordel.
Ud over de her omtalte partier levnes ingen nogen som helst chancer ved valget; det gælder også skakverdensmesteren Garry Kasparovs Forenede Borgerfront i bevægelsen 'Det andet Rusland', der ikke figurerede på Den Centrale Valgkomités liste over opstillingsberettigede partier i midten af september.

\section{Partiernes popularitet}

Ved starten af valgkampen forelå der to opinionsmålinger fra de ledende institutter. Den ene var fra august 2007 og gav følgende billede af stemmefordelingen: Forenet Rusland - 59 procent, KPRF - 18 procent, Retfærdigt Rusland - 9 procent, LDPR - 7 procent, Jabloko - 3 procent, Unionen af Højrekræfter 1 procent; den anden var fra 8.-9. september: Forenet Rusland - 45 procent, KPRF - 8 procent, Retfærdigt Rusland -5 procent, LDPR 6procent, Jabloko - 1 procent, Unionen af Højrekræfter - 1 procent.

Som nævnt menes de første tre partier trods disse tal at komme over spærregrænsen på 7 procent af stemmerne og blive repræsenteret $\mathrm{i}$ Dumaen, idet Forenet Ruslands gruppe forventes at blive reduceret noget uden dog at blive mindre end 226, der kræves for at have almindeligt flertal.

Selvom Jabloko står en anelse bedre i den ene meningsmåling, forventes kampen om at blive det fjerde parti i Dumaen at komme til at 
stå mellem LDPR og Unionen af Højrekræfter. Novoje vremja/New Times mener ligefrem, at det vil blive afgjort i præsidentens administration, der ifølge en anden kilde skulle være godt træt af Zjirinovskij. Ugebladet mener også, at der ikke er plads til et femte parti i Dumaen, da det vil røve mandater fra Forenet Rusland. Det skal i denne forbindelse bemærkes, at partierne i midten af september endnu ikke havde holdt deres kongresser eller lanceret deres valgprogrammer. Meget kunne således nå at ændre sig under valgkampen; meget ville afhænge af navnene på partilisterne og af partiernes propaganda.

\section{Valg og valgkamp}

Ved valget vil hele Rusland udgøre én valgkreds, den føderale, og her kan partierne opstille tre kandidater hver, de såkaldte trojkaer, med fremtrædende kandidater, såkaldte lokomotiver, der skal trække vælgerne til, men ikke nødvendigvis agter at blive medlemmer af Dumaen. Herudover skal partierne efter nogle indviklede regler opstille 80 regionale grupper af kandidater, idet den regionale del af den føderale partiliste skal omfatte alle 84 regioner i landet.

Det indviklede består i bestemmelserne for de regionale gruppers størrelse, hvortil kommer, at grupperne skal grænse op til hinanden, og at partierne af partitaktiske årsa- ger formentlig vil inddele landet $\mathrm{i}$ forskellige grupper.

Naboskabet er allerede blevet fortolket vidt til fordel for Forenet Rusland, der har fået lov til at samle øen Sakhalin, Kamtjaka-regionen og Khabarovsk-regionen i én gruppe, selvom Det Okhotske Hav vidtstrakte vandmasser adskiller dem. Og det ser ud til, at den lille republik Adygeja i Nordkaukasus, der ifølge reglerne ikke kan sluttes sammen med Krasnodar-regionen, som ellers omgiver den, må slutte sig sammen med Kaliningrad-regionen, der som eksklave uden naboer kan slutte sig sammen med hvilken som helst region.

Da interessen for politik og tilliden til partierne ikke er stor hos vælgerne, må partierne oppe sig for at tiltrække dem. Deres propaganda vil dog være hæmmet af visse bestemmelser vedrørende bekæmpelse af ekstremisme. Således må de ikke bekæmpe hinanden i tv-reklamer og gennem tv-agitatorer, men derimod godt i tv-debatter, i radio og i pressen. Man frygter dog anvendelse af en del 'sort' pr og administrative resurser, dvs. forskellige lederes brug af rådige midler til at fremme egne mål, ligesom man forventer at se populistiske tilbøjeligheder hos partierne.

Pr. 1. juni udgjorde vælgerkorpset 107.062.709 personer, hvilket er godt 600.000 færre end i 2003 ; hertil kommer skønsmæssigt 1,6 mio. russiske vælgere i udlandet. Borgerne har stemmeret, når de er 18 år, 
og er valgbare, når de er 21 år. Personer, der er umyndiggjort ved dom, og personer, der afsoner straffe i fængslerne, har ingen stemmeret. Der er ca. 100.000 valgsteder med halvanden mio. tilforordnede, som forventes overvåget af halvanden mio. partiobservatører samt eventuelle udenlandske observatører. Da rollerne på den russiske politiske scene i nogen grad skifter fra valg til valg, vil der blive trukket lod om partiernes placering på stemmesedlen. Skulle Forenet Rusland komme til at stå øverst, vil de færreste nok tro, at det er et tilfælde.

\section{Valgresultatet}

Der er delte meninger om pålideligheden af det kommende valgresultat. Mange tror ikke på muligheden af ærlige valg, mens Moskovskije novostis chefredaktør, Vitalij Tretjakov mener, at Putin med udnævnelsen af en ny formand for Den Centrale Valgkommission i begyndelsen af 2007 ville sikre sig 'maksimalt ærlige valg med et maksimalt objektivt resultat'. Ifølge ham vil Putin ikke be- skyldes for valgfusk af Vesten, og Kreml vil kende sandheden.

Hvordan den nye Duma end bliver sammensat, skal den ikke danne regering på grundlag af et flertal; det gjorde præsidenten i god tid før valget, og den skal foreløbig heller ikke vedtage en finanslov, for den afgående Duma forventes at vedtage en tre-årig finanslov for 2008-2010. Dumaen kommer faktisk næppe i gang med arbejdet før efter præsidentvalget i marts 2008 - eller rettere før den nyvalgte præsidents tale til nationen.

Og så skal det vise sig, om det er et sted, hvor der skal diskuteres.

\section{Lars P. Poulsen-Hansen er konsulent} vedrørende det tidligere Sovjetunionens historie og geografi på internetudgaven af nationalencyklopedien.

Artiklen er afleveret medio september, altså inden 'Forenet Ruslands' kongres $i$ begyndelsen af oktober. Her meddelte Putin, at han stiller op til parlamentsvalget for 'Forenet Rusland'. 